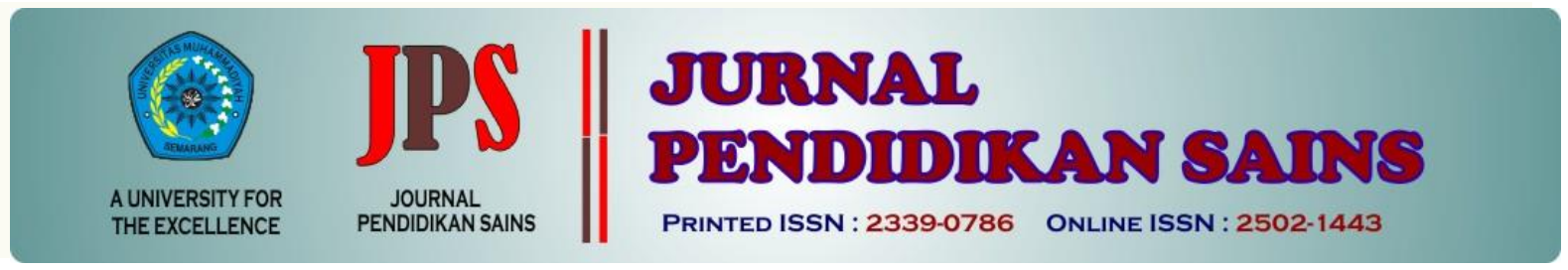

http://jurnal.unimus.ac.id/index.php/JPKIMIA

\title{
PENGUJIAN VALIDITAS DAN PRAKTIKALITAS TES DISPOSISI BERPIKIR KRITIS DALAM BIOLOGI (TDBKB)
}

\author{
Oleh: \\ Jayanti Syahfitri ${ }^{1}$, Harry Firman ${ }^{2}$, Sri Redjeki ${ }^{2}$, dan Siti Sriyati ${ }^{2}$ \\ ${ }^{1}$ Universitas Muhammadiyah Bengkulu \\ Jayanti_syahfitri@yahoo.co.id \\ ${ }^{2}$ Universitas Pendidikan Indonesia
}

\begin{tabular}{|c|c|c|}
\hline Article hist & & Abstract \\
\hline Submission & : 2018-12-27 & \multirow{5}{*}{$\begin{array}{l}\text { A good instrument is not only seen from the validity and reliability, } \\
\text { but also from practical values. The purpose of this study is to examine } \\
\text { the validity and practicality of the critical thinking disposition test in } \\
\text { biology. This study involved } 73 \text { students of Biology Education as } \\
\text { samples taken from the } 1 \text { st and 3rd study levels. The instruments used } \\
\text { in this study were the drafts of critical thinking disposition tests in } \\
\text { biology and also response questionnaires. This study uses the Content } \\
\text { Validity Ratio (CVR) and Confirmatory Factor Analysis (CFA) } \\
\text { method. The draft of a critical thinking disposition test in biology was } \\
\text { validated by six validators. Based on the findings indicate that the } \\
\text { critical thinking disposition test in biology has good validity and } \\
\text { practical value. }\end{array}$} \\
\hline Revised & : 2019-02-19 & \\
\hline Accepted & : 2019-03-16 & \\
\hline \multicolumn{2}{|l|}{ Keyword: } & \\
\hline \multicolumn{2}{|c|}{$\begin{array}{l}\text { Pengujian, validitas, } \\
\text { praktikalitas, tes disposisi } \\
\text { berpikir kritis biologi }\end{array}$} & \\
\hline
\end{tabular}

\section{Pendahuluan}

Facione (1990) menjelaskan bahwa selain keterampilan atau kemampuan, berpikir kritis juga meliputi disposisi yang kedua komponen ini merupakan domain general dan spesifik dari berpikir kritis. Facione (2000) juga mengungkapkan bahwa pada kenyataannya gagasan tentang berpikir kritis dan disposisi ini merupakan dua hal yang berbeda. Disposisi terhadap berpikir kritis sebagai motivasi internal yang konsisten untuk terlibat masalah dan membuat keputusan dengan menggunakan pemikiran kritis.

Foluso (2014) mengungkapkan bahwa dorongan, peningkatan, dan penekanan pada kebutuhan untuk disposisi terhadap pemecahan masalah sangat penting. Pendidik dengan disposisi berpikir kritis yang kuat akan mendorong siswa untuk kritis merefleksikan kualitas pemikiran mereka saat mereka terlibat dalam pengajaran dan pembelajaran dan akan terus memantau proses berpikir mereka. Selanjutnya Yuksel dan Alci (2012) mengungkapkan bahwa disposisi seorang peserta didik untuk berpikir kritis merupakan prasyarat yang diperlukan untuk berpikir kritis, dan itu sangat mempengaruhi kemampuan berpikir kritis. Selanjutnya Facione et al., (1995) mengelompokkan disposisi berpikir kritis dalam tujuh indikator yaitu truth-seeking, open-mind, analyticity, systematicity, selfconfidence, inquisitiveness, dan maturity.

Menurut Ghadi et al., (2012) validitas merupakan suatu ukuran yang menunjukkan kesahihan dari suatu tes. Suatu tes dikatakan

*Corresponding Author:

$\begin{array}{ll}\text { Nama } & \text { : Jayanti Syahfitri } \\ \text { Lembaga } & \text { : Universitas Muhammadiyah Bengkulu } \\ \text { Email } & \text { : jayanti_syahfitri@ yahoo.co.id }\end{array}$


valid atau sahih apabila tes dapat mengukur apa yang hendak diukur. Validitas dikelompokkan menjadi tiga jenis yaitu validitas konten, validitas konstruk dan validitas prediksi. Validitas konten atau isi merupakan validitas yang dalam prosesnya melibatkan kegiatan yang menetapkan representatif item dengan domain kemampuan, tugas, pengetahuan dan lain-lain. Validasi konten atau isi membutuhkan analisis rasional dari seseorang yang ahli dalam bidang yang dikembangkan alat ukur tersebut atau professional judgement.

Selain suatu instrumen harus memiliki kualitas kevalidan yang baik, perlu juga dilihat bagaimana kualitas kepraktisan tes tersebut di lapangan atau penggunaan di dalam kelas. Sesuai dengan pernyataan Poerwati dan Masduki (2008) bahwa kualitas kepraktisan diartikan bahwa tes tidak sulit untuk dilaksanakan dilihat dari segi pembiayaan maupun pelaksanaanya. Selanjutnya Dwijayani (2017) mengungkapkan bahwa tes yang baik harus efisien dan mudah untuk dilaksanakan. Kualitas suatu produk dapat dilihat dari tiga kriteria yaitu kevalidan, kepraktisan, dan efektifitas. Mahasiswa sebagai responden berperan dalam hal memperoleh data tentang kepraktisan dan keefektifan. Hal ini sejalan dengan pernyataan Prilianti (2012) bahwa untuk menentukan kualitas hasil pengembangan model dan perangkat pembelajaran diperlukan tiga kriteria: kevalidan, kepraktisan, dan keefektifan.

Suparmin dkk (2012) menjelaskan bahwa suatu instrumen dapat dikatakan memiliki nilai kepraktisan yaitu jika instrumen tersebut memiliki kemudahan dalam beberapa hal. Kepraktisan suatu instrumen dapat dilihat dari sejauhmana kemudahan instrumen tersebut dalam mempersiapkan, menggunakan, menginterpretasi, memperoleh hasil, maupun kemudahan dalam menyimpan. Selain itu, kepraktisan suatu instrumen juga dapat dilihat dari kemudahan dalam mengadministrasi, waktu yang disediakan untuk melakukan kegiatan evaluasi, kemudahan menskor, kemudahan dalam menginterpretasi dan aplikasinya.

Berdasarkan latar belakang yang menjelaskan bahwa pentingnya melihat validitas dan nilai kepraktisan suatu tes yang dikembangkan sebagai bentuk upaya menentukan kualitas tes tersebut, sehingga perlu adanya penelitian terkait "Pengujian Validitas dan Praktikalitas Tes Disposisi Berpikr Kritis dalam Biologi (TDBKB)". Hal ini dilakukan dengan tujuan untuk memperoleh Tes Disposisi Berpikir Kritis dalam Biologi (TDBKB) yang terstandarisasi, sehingga dapat digunakan sebagai instrumen alternatif dalam melihat disposisi berpikir kritis mahasiswa Pendidikan Biologi di Perguruan Tinggi.

\section{Metode Penelitian}

Pada penelitian ini menggunakan metode Content Validity Ratio (CVR) dan Confirmatory Factor Analysis (CFA). Content Validity Ratio (CVR) yang digunakan untuk melihat validitas konten draf Tes Disposisi Berpikir Kritis dalam Biologi (TDBKB) yang telah dilakukan oleh sejumlah ahli. Sedangkan metode Confirmatory Factor Analysis (CFA) digunakan untuk melihat validitas konstruk Tes Disposisi Berpikir Kritis dalam Biologi (TDBKB). Prosedur pada metode Confirmatory Factor Analysis (CFA) dikenal dengan istilah convergent validity yang terdiri atas tiga tahap yaitu analisis factor laoding dengan nilai terima $>0,5$, analisis reliability dengan nilai terima 0,7, dan analisis Average Extract Variance (AVE) dengan nilai terima $>0,5$. Selain itu, dalam penelitian ini juga mendeskripsikan tentang nilai kepraktisan Tes Disposisi Berpikir Kritis dalam Biologi (TDBKB) pada saat digunakan dalam mengukur disposisi berpikir kritis mahasiswa Pendidikan Biologi.

Penelitian ini terdiri atas beberapa tahap yaitu pertama, mengembangkan draf Tes Disposisi Berpikir Kritis dalam Biologi (TDBKB). Kedua, memvalidasi draf Tes Disposisi Berpikir Kritis dalam Biologi (TDBKB) yang dikembangkan (validitas konten dan validitas konstruk). Ketiga, menggunakan Tes Disposisi Berpikir Kritis dalam Biologi (TDBKB) yang telah terstandarisasi diikuti dengan memberikan lembar angket respon terhadap penggunaan Tes Disposisi Berpikir Kritis dalam Biologi (TDBKB). Hal ini dilakukan untuk mendapatkan data atau informasi tentang praktikalitas instrumen Tes Disposisi Berpikir Kritis dalam Biologi (TDBKB) yang dikembangkan.

Pada tahap validasi konten, peneliti melibatkan enam orang ahli atau validator yang menilai kesesuaian konten draf Tes Disposisi Berpikir Kritis dalam Biologi (TDBKB) yang dikembangkan. Adapun responden yang dilibatkan dalam tahap validasi konstruk yaitu sebanyak 526 orang mahasiswa Pendidikan Biologi dari dua Universitas di Bengkulu. 
Sedangkan pada tahap uji coba praktikalitas Tes Disposisi Berpikir Kritis dalam Biologi (TDBKB) hanya melibatkan 73 orang mahasiswa Pendidikan Biologi sebagai subjek dalam penelitian. Subjek tersebut diambil dari mahasiswa Pendidikan Biologi pada semester 1 yaitu sebanyak 38 orang dan semester 3 yaitu sebanyak 35 orang.

Instrumen atau alat pengumpul data yang digunakan dalam penelitian ini yaitu draf Tes Disposisi Berpikir Kritis dalam Biologi (TDBKB) yang digunakan untuk melihat validitas konten, Tes Disposisi Berpikir Kritis dalam Biologi (TDBKB) yang telah terstandarisasi digunakan untuk melihat profil disposisi berpikir kritis mahasiswa Pendidikan Biologi. Sedangkan lembar angket digunakan untuk memperoleh data tentang respon atau tanggapan terhadap Tes Disposisi Berpikir Kritis dalam Biologi (TDBKB).

Analisis data yang digunakan dalam penelitian ini terdiri atas tiga yaitu pertama analisis deskriptif yang dilakukan dengan bantuan aplikasi software SPSS versi 20 untuk melihat data respon atau tanggapan dari mahasiswa Pendidikan Biologi. Kedua, analisis Confirmatory Factor Analysis (CFA) dengan bantuan aplikasi AMOS versi 20 untuk melihat validitas konstruk. Sedangkan dalam melihat validitas konten Tes Disposisi Berpikir Kritis dalam Biologi (TDBKB) data dianalisis melalui metode Content Validity Ratio (CVR). Conten Validity Ratio (CVR) merupakan metode yang digunakan untuk menganalisis hasil validasi konten. Metode ini diusulkan oleh Lawshe (1975) yang merupakan tranformasi linear tingkat kesepakatan yang proporsional tentang berapa banyak ahli dalam panel yang menilai item "essensial". Selanjutnya Ayre and Scally (2014) menjelaskan bahwa CVR $_{\text {critical }}$ value dapat digunakan untuk menentukan berapa banyak anggota validator (ahli) yang menyetujui butir soal, sehingga dapat disimpulkan butir soal mana yang harus dimasukan atau dbuang dari instrumen sebagai hasil konstruksi akhir.

\section{Hasil Penelitian dan Pembahasan}

Berdasarkan hasil validasi konten terhadap draf Tes Disposisi Berpikir Kritis dalam Biologi (TDBKB) yang dianalisis melalui Content Validity Ratio (CVR) menunjukkan bahwa secara keseluruhan konstruksi soal Tes Disposisi Berpikir Kritis dalam Biologi (TDBKB) adalah valid. Konstruk pada Tes Disposisi Berpikir Kritis dalam Biologi (TDBKB) dinyatakan memiliki validitas konten yang baik. Validasi konten dilihat dari dua aspek yaitu aspek kesesuaian dengan materi biologi dan dari aspek kesesuaian dengan disposisi berpikir kritis. Hal ini dapat dilihat dari rekapitulasi hasil validasi konten dari sejumlah ahli pada Tabel 1.

Tabel 1. Rekapitulasi hasil validasi konten dari sejumlah ahli

\begin{tabular}{llccccccc}
\hline \multirow{2}{*}{ No } & Butir Soal yang & \multicolumn{7}{c}{ Keputusan Validator } \\
\cline { 3 - 7 } & Mewakili & 1 & 2 & 3 & 4 & 5 & 6 & Validitas \\
\hline 1 & Truth-Seeking & Setuju & Setuju & Setuju & Setuju & Setuju & Setuju & Baik \\
2 & Open-Mind & Setuju & Setuju & Setuju & Setuju & Setuju & Setuju & Baik \\
3 & Analyticity & Setuju & Setuju & Setuju & Setuju & Setuju & Setuju & Baik \\
4 & Systematicity & Setuju & Setuju & Setuju & Setuju & Setuju & Setuju & Baik \\
5 & Self-Confidence & Setuju & Setuju & Setuju & Setuju & Setuju & Setuju & Baik \\
6 & Inquisitiveness & Setuju & Setuju & Setuju & Setuju & Setuju & Setuju & Baik \\
7 & Maturity & Setuju & Setuju & Setuju & Setuju & Setuju & Setuju & Baik \\
\hline
\end{tabular}

Pada Tabel 1 mendeskripsikan bahwa semua butir soal yang mewakili tujuh indikator disposisi berpikir kritis memiliki validitas konten yang baik yaitu memiliki nilai CVR dengan rentang 0,67 sampai dengan 1 . Hal ini membuktikan bahwa nilai CVR pada butir soal Tes Disposisi Berpikir Kritis dalam Biologi (TDBKB) lebih besar dari nilai kritis pada Content Validity Ratio (CVR) untuk enam orang validator yaitu 0,64 (Wilson, 2012).
Nilai Content Validity Ratio (CVR) 1 memiliki arti bahwa semua validator atau ahli menyetujui konstruk item yang dikembangkan. Sedangkan nilai Content Validity Ratio (CVR) 0,67 menjelaskan bahwa hanya satu orang ahli yang menyatakan tidak setuju terhadap konstruk item yang dikembangkan.

Temuan pada analisis Content Validity Ratio (CVR) ini menjelaskan bahwa terdapat beberapa item soal yang tidak disetujui oleh satu orang ahli. Terdapat beberapa konstruk 
item pada soal yang dikembangkan pada penelitian ini hanya disetujui oleh lima orang validator atau ahli. Jika dilihat dari nilai minimum atau nilai kritis dari Content Validity Ratio (CVR) untuk enam orang ahli, maka dapat disimpulkan bahwa seluruh konstruk item soal pada draf Tes Disposisi Berpikir Kritis dalam Biologi (TDBKB) memiliki validitas konten yang baik.

Berdasarkan hasil analisis convergent validity juga menunjukan bahwa sepuluh butir soal pada Tes Disposisi Berpikir Kritis dalam Biologi (TDBKB) memiliki nilai factor loading di atas 0,5 dan nilai reliabilitas $0,98(>0,7)$. Sedangkan untuk nilai Average Variance Extract (AVE) dapat dilihat pada Tabel 2.

Tabel 2. Nilai Average Variance Extract (AVE)

\begin{tabular}{clc}
\hline No & $\begin{array}{c}\text { Indikator } \\
\text { Disposisi Berpikir } \\
\text { Kritis }\end{array}$ & $\begin{array}{c}\text { Average Variance } \\
\text { Extract (AVE) }\end{array}$ \\
\hline 1 & Truth-Seeking & 0,72 \\
2 & Open-Mind & 0,62 \\
3 & Analyticity & 0,76 \\
4 & Systematicity & 0,69 \\
5 & Self-Confidence & 0,83 \\
6 & Inquisitiveness & 0,56 \\
7 & Maturity & 0,75 \\
\hline
\end{tabular}

Pada Tabel 2 dapat dilihat bahwa semua indikator disposisi berpikir kritis pada Tes Disposisi Berpikir Kritis dalam Biologi (TDBKB) memiliki nilai Average Variance Extract (AVE) di atas 0,5 (dapat diterima). Hal ini didukung dengan pernyataan Hair et al., (2010) bahwa nilai terima Average Variance Extract (AVE) adalah lebih besar dari 0,5. Berdasarkan hasil temuan pada analisis convergent validity dapat disimpulkan bahwa Tes Disposisi Berpikir Kritis dalam Biologi (TDBKB) memiliki validitas konstruk yang baik (dapat diterima), sehingga dapat digunakan dalam mengukur disposisi berpikir kritis mahasiswa Pendidikan Biologi.

Selanjutnya pada tahap penggunaan Tes Disposisi Berpikir Kritis dalam Biologi (TDBKB) yang telah dilakukan pada mahasiswa Pendidikan Biologi, peneliti juga menyebarkan angket respon atau tanggapan mahasiswa terhadap Tes Disposisi Berpikir Kritis dalam Biologi (TDBKB). Hal ini bertujuan untuk mengetahui tanggapan mahasiswa terhadap Tes Disposisi Berpikir Kritis dalam Biologi (TDBKB) yang dikembangkan. Angket disusun dengan

beberapa pernyataan dengan skala penilaian yaitu skala Likert empat pilihan jawaban yaitu Sangat Setuju (SS), Setuju (S), Tidak Setuju (TS), dan Sangat Tidak Setuju (STS). Adapun hasil angket respon mahasiswa terhadap Tes Disposisi Berpikir Kritis dalam Biologi (TDBKB) dapat dilihat pada Tabel 3.

Tabel 3. Rekapitulasi Respon Angket Mahasiswa Terhadap TDBKB

\begin{tabular}{|c|c|c|c|}
\hline No & Pernyataan & $\begin{array}{l}\text { Skor } \\
\text { Total }\end{array}$ & $\begin{array}{c}\text { Persentase } \\
(\%)\end{array}$ \\
\hline 1 & $\begin{array}{l}\text { Pedoman dalam } \\
\text { mengerjakan tes } \\
\text { disampaikan } \\
\text { denggan tegas dan } \\
\text { jelas }\end{array}$ & 244 & 78 \\
\hline 2 & $\begin{array}{l}\text { Bahasa yang } \\
\text { digunakan dalam tes } \\
\text { mudah dipahami } \\
\text { dan tidak } \\
\text { mengandung } \\
\text { ambiguitas }\end{array}$ & 242 & 78 \\
\hline 3 & $\begin{array}{l}\text { Istilah ilmiah yang } \\
\text { digunakan dalam tes } \\
\text { jelas dan mudah } \\
\text { dipahami }\end{array}$ & 243 & 78 \\
\hline 4 & $\begin{array}{l}\text { Permasalahan pada } \\
\text { kasus dan } \\
\text { pertanyaan } \\
\text { disajikan dengan } \\
\text { jelas }\end{array}$ & 250 & 80 \\
\hline 5 & $\begin{array}{l}\text { Gambar pada tes } \\
\text { disajikan dengan } \\
\text { jelas, mudah } \\
\text { dipahami, dan dapat } \\
\text { membantu dalam } \\
\text { membaca dan } \\
\text { mengerjakan soal }\end{array}$ & 244 & 78 \\
\hline 6 & $\begin{array}{l}\text { Pertanyaan- } \\
\text { pertanyaan dalam } \\
\text { tes mendorong } \\
\text { mahasiswa untuk } \\
\text { cenderung berpikir } \\
\text { kritis }\end{array}$ & 247 & 79 \\
\hline 7 & $\begin{array}{l}\text { Tes disposisi } \\
\text { berpikir kritis } \\
\text { disajikan secara } \\
\text { menarik }\end{array}$ & 245 & 79 \\
\hline 8 & $\begin{array}{l}\text { Mahasiswa menjadi } \\
\text { tertarik dalam } \\
\text { membaca dan } \\
\text { mengerjakan tes }\end{array}$ & 237 & 76 \\
\hline \multicolumn{3}{|c|}{ Persentase (\%) Rata-Rata } & $\begin{array}{c}78 \\
\text { (Baik) }\end{array}$ \\
\hline
\end{tabular}


Berdasarkan Tabel 3 dapat dilihat bahwa tingkat kepraktisan Tes Disposisi Berpikir Kritis dalam Biologi (TDBKB) adalah dikategorikan baik yaitu dengan rata-rata kriteria ( $78 \%$ ). Selain itu hasil angket respon menjelaskan adanya respon yang positif terhadap tes dengan respon terbanyak yang diberikan oleh mahasiswa yaitu pada respon Setuju (S) sedangkan untuk respon Sangat Tidak Setuju (STS) tidak ditemukan.

Selanjutnya jika dilihat dari waktu yang diperlukan mahasiswa dalam mengerjakan soal tersebut yaitu 150 menit untuk jumlah soal 10 kasus dengan masing-masing 7 pertanyaan. Dengan demikian mahasiswa hanya memerlukan waktu lebih kurang 2 menit dalam mengerjakan setiap soal pada Tes Disposisi Berpikir Kritis dalam Biologi (TDBKB). Sehingga dapat disimpulkan bahwa Tes Disposisi Berpikir Kritis dalam Biologi (TDBKB) merupakan instrumen yang memiliki efisiensi yang baik dan mudah dilakukan atau digunakan. Sedangkan jika dilihat dari segi biaya, sama seperti alat evaluasi lainnya bahwa Tes Disposisi Berpikir Kritis dalam Biologi (TDBKB) tidak memerlukan biaya yang besar, karena tes hanya terdiri atas beberapa soal yang dapat dikerjakan dalam sekali pertemuan. Selain itu dalam penggunaannya dosen hanya perlu mengawasi mahasiswa dalam mengerjakan soal. Mahasiswa dapat langsung mengerjakan soal dengan baik karena Tes Disposisi Berpikir Kritis dalam Biologi (TDBKB) dilengkapi dengan panduan yang jelas dalam mengerjakan soal. Gambar-gambar pada kasus ditampilkan berwarna, sehingga dapat membantu mahasiswa lebih jelas dalam memahami kasus pada soal.

Hasil temuan juga menunjukkan bahwa bahwa Tes Disposisi Berpikir Kritis dalam Biologi (TDBKB) dapat dipahami dengan baik oleh mahasiswa, istilah ilmiah dan bahasa yang digunakan dalam pertanyaan mudah tegas dan mudah dipahami. Tampilan Tes Disposisi Berpikir Kritis dalam Biologi (TDBKB) yang menarik membuat mahasiswa dapat mengerjakan soal dengan antusias. Selain itu gambar disajikan dengan jelas dan tidak mengandung ambiguitas sehingga dapat membantu mahasiswa dalam memahami soal. Dengan mengerjakan Tes Disposisi Berpikir Kritis dalam Biologi (TDBKB) dapat mendorong mahasiswa untuk berpikir kritis. Hal ini disebabkan karena Tes Disposisi Berpikir Kritis dalam Biologi (TDBKB) disajikan dengan kasus dan karakteristik pertanyaan yang menggiring mahasiswa untuk cenderung berpikir kritis.

Berdasarkan beberapa hasil temuan dan pembahasan dari penelitian tersebut dapat disimpulkan bahwa Tes Disposisi Berpikir Kritis dalam Biologi (TDBKB) memiliki nilai praktis yang tergolong baik. Beberapa temuan tersebut sejalan dengan pernyataan Adlia dan Ellbert (2017) yang menjelaskan bahwa kepraktisan suatu instrumen dilihat dari seberapa mudah instrumen tersebut untuk digunakan oleh orang lain. Selain itu instrumen tersebut dianggap menarik, menyenangkan dan berguna. Sedangkan suatu instrumen dapat dikatakan efektif jika instrumen tersebut mampu mencapai tujuan yang diinginkan (ketercapaian tujuan). Selain itu Putu (2017) juga menjelaskan bahwa efektif mengandung makna bahwa suatu instrumen yang digunakan adalah tepat guna sesuai dengan keadaan yang dikehendaki. Sedangkan efisiensi memiliki arti ketepatan cara (usaha, kerja) dalam menjalankan sesuatu (dengan tidak membuang waktu, tenaga, biaya).

\section{Simpulan dan Saran}

\section{Simpulan}

Berdasarkan hasil temuan dalam penelitian ini dapat disimpulkan bahwa Tes Disposisi Berpikir Kritis dalam Biologi (TDBKB) memiliki validitas konten dengan kategori baik untuk semua butir soal yang mewakili indikator disposisi berpikir kritis.

Selanjutnya kepraktisan instrumen Tes Disposisi Berpikir Kritis dalam Biologi (TDBKB) tergolong baik. Mahasiswa memberikan respon positif terhadap tes yang digunakan.

\section{Saran}

Berdasarkan temuan dalam penelitian ini, peneliti merekomendasikan kepada peneliti selanjutnya yang akan meneliti variabel yang sama untuk menggunakan Tes Disposisi Berpikir Kritis dalam Biologi (TDBKB) yang valid, praktis dan efektif (terstandarisasi) dalam mengukur disposisi berpikir kritis seseorang. Tes Disposisi Berpikir Kritis dalam Biologi (TDBKB) dapat menjadi pilihan sebagai instrumen alternatif untuk melihat sejauhmana profil disposisi mahasiswa Pendidikan Biologi secara lebih objektif. 


\section{Ucapan Terima Kasih}

Ucapan terima kasih author sampaikan kepada kepada semua pihak yang telah membantu dalam pelaksanaan penelitian ini, khususnya kepada rekan sejawat dari Fakultas Keguruan dan Ilmu Pendidikan Biologi di Universitas Muhammadiyah Bengkulu.

\section{Daftar Pustaka}

Adlia, A dan Ellbert, H. (2017). Kepraktisan dan Keefektifan Modul Pembelajaran Bilingual berbasis Komputer. Jurnal Kependidikan, 1, 12-23.

Ayre, C. and Scally, A. J. (2014). Critical values for Lawshe's content validity ratio: revisiting the original methods of calculating. Measurement and Evaluation in Counseling and Development, 47, 79-86.

Dwijayani, N. M. (2017). Pengembangan Media Pembelajaran ICARE. Kreano: Jurnal Matematika KreatifInovatif, 1, $126-132$.

Facione, P. A. (1990). Critical thinking: A statement of expert consensus for purposes of educational assessment and instruction. Millbrae, CA: The California Academic Press.

Facione, P. A. (2000). The disposition toward critical thinking: Its character, measurement, and relation to critical thinking skill. Informal Logic, 20, 61-84.

Facione P. A., Giancarlo \& Joanne, G. (1995). The disposition toward critical thinking. Journal of General Education, 44, 1-25.

Foluso, O. (2014). Critical thinking dispositions of nursing faculty in Southwestern Nigeria International Journal of Research in Applied, Natural and Social Sciences (IMPACT: IJRANSS), 2, 127-134.

Ghadi, I., Nor, H. A., and Bakar, K. A. (2012). Construct Validity Examination of Critical Thinking Dispositions for Undergraduate Students in University Putra Malaysia. Journal Higher Education Studies, 2, 138145.
Hair, J. F., Black, W. C., Balin, B. J., and Anderson, R. E. (2010). Multivariate data analysis (Maxwell Macmillan International Editions).

Lawshe, C. H. (1975). A quantitative approach to content validity. Personnel Psychology, 28, 563-575.

Masduki dan Poerwati, E. (2008). Mengembangkan Tes Sebagai Instrumen Evaluasi. Assesment Pembelajaran. Universitas Muhammadiyah Malang: UMM Pers, Malang.

Prilianti, R. (2012). Pengembangan Perangkat Pembelajaran Pendalaman Materi Kimia Redoks Berbasis. (Artikel Thesis). Universitas Negeri Semarang.

Putu, D. W. (2017). Analisis Pengukuran Tingkat Efektivitas dan Efisiensi Sistem Informasi Manajemen Surat STIKOM Bali. Jurnal Sistem Dan Informatika, 11, 99-109.

Suparmin, Abu, U, Giyoto, dan Fauzi, A. (2012). Validitas, Reliabilitas, dan Kepraktisan UjianMelalui Observasi dan Bentuk Lisan Bagi Kelas Besar Pada Prodi Pai Fakultas Tarbiyah dan Bahasa Iain Surakarta. Kodifikasia, 6, 1-12.

Wilson, F. R., Pan, W., and Schumsky, D. A. (2012). Recalculation of the critical values for Lawshe's content validity ratio. Measurement and Evaluation in Counseling and Development, 45, 197-210.

Yuksel, B dan Alci, B. (2012). Self-Efficacy and Critical Thinking Disposition as Predictors of Success in School Practicum. International Online Journal of Educational Sciences, 4, $81-90$ 